\title{
INTERNATIONAL JOURNAL OF

\section{Value Orientation as Resistance to Utility of STEM-Driven Innovations to Promote Environmental Conservation among Public}

Sharifah Intan Sharina Syed Abdullah, Zaida Nor Zainuddin, Edy Hafizan Mohd Shahali, Norshariani Abd Rahman, Fitriya Abd Rahim

To Link this Article: http://dx.doi.org/10.6007/IJARBSS/v9-i11/6714

DOI: 10.6007/IJARBSS/v9-i11/6714

Received: 12 October 2019, Revised: 30 October 2019, Accepted: 14 November 2019

Published Online: 30 November 2019

In-Text Citation: (Abdullah et al, 2019)

To Cite this Article: Abdullah, S. I. S. S., Zainuddin, Z. N., Shahali, E. H. M., Rahman, N. A., \& Rahim, F. A. (2019). Value Orientation as Resistance to Utility of STEM-Driven Innovations to Promote Environmental Conservation among Public. International Journal of Academic Research in Business and Social Sciences, 9(11), 1495-1505.

Copyright: (C) 2019 The Author(s)

Published by Human Resource Management Academic Research Society (www.hrmars.com)

This article is published under the Creative Commons Attribution (CC BY 4.0) license. Anyone may reproduce, distribute, translate and create derivative works of this article (for both commercial and non-commercial purposes), subject to full attribution to the original publication and authors. The full terms of this license may be seen

at: http://creativecommons.org/licences/by/4.0/legalcode

Vol. 9, No. 11, 2019, Pg. 1495 - 1505

http://hrmars.com/index.php/pages/detail/IJARBSS

JOURNAL HOMEPAGE

Full Terms \& Conditions of access and use can be found at http://hrmars.com/index.php/pages/detail/publication-ethics 


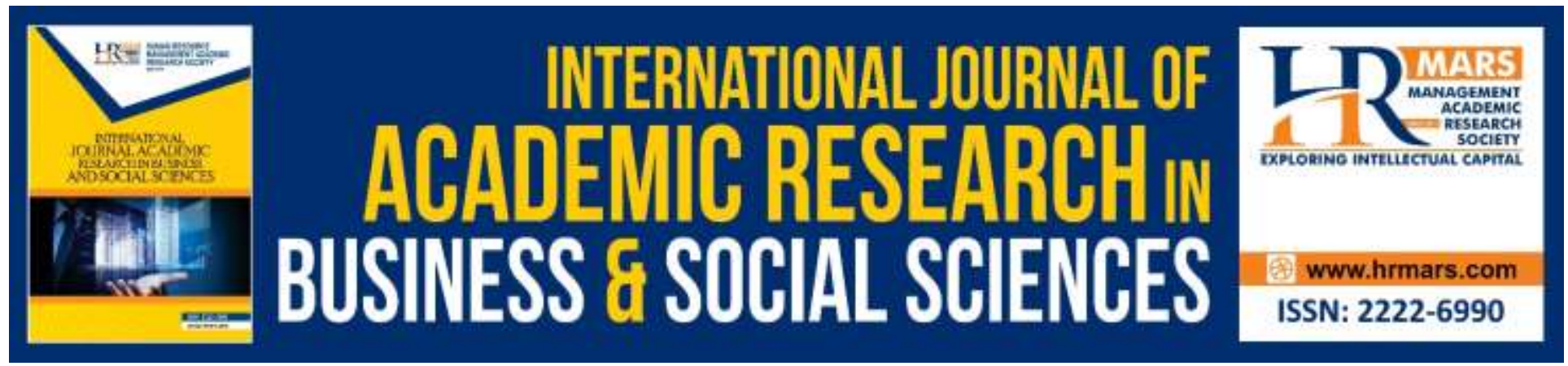

\title{
Value Orientation as Resistance to Utility of STEM- Driven Innovations to Promote Environmental Conservation among Public
}

\section{Sharifah Intan Sharina Syed Abdullah", Zaida Nor Zainuddin', Edy Hafizan Mohd Shahali², Norshariani Abd Rahman³, Fitriya Abd Rahim ${ }^{4}$}

${ }^{1}$ Faculty of Educational Studies, Universiti Putra Malaysia (UPM), 43400 Selangor, Malaysia, ${ }^{2}$ Faculty of Education, National University of Malaysia, 43600 Selangor, Malaysia, ${ }^{3}$ Institute of

Islam Hadhari, National University of Malaysia, 43600 Selangor, Malaysia, ${ }^{4}$ Faculty of

Accountancy and Management, Universiti Tunku Abdul Rahman, 43000 Selangor, Malaysia

\begin{abstract}
Innovations is one of STEM products that will significantly impact people's life. However, the ability of STEM-driven innovation to solve a particular problem may be different from one place to another. It depends on the values preserved by a particular society. This study investigate how value orientation may be the resistance to utility of reverse vending machine (RVM). The current study adopted qualitative research approach. Qualitative data were collected from Malaysian public through comments they left on an article posted on a Facebook group page about RVM. The 281 comments were analyzed thematically. Three themes presented in this article are: i) egoistic oriented response; ii) biospheric oriented response; and iii) anticipation of the adverse effects of reverse vending machine. This study suggests there is a need for education reorientation, especially STEM education in Malaysia. STEM education should develop thinking citizens that are able to think and make their own decisions based on sound judgment in determining what counts as proper behavior.
\end{abstract}

Keywords: STEM, Innovations, Value Orientations, Environmental Conservation

\section{Introduction}

The hasty growth of industrial revolution throughout the global world has defied the traditional teaching approach of science education in Malaysia. Prior approach of teaching science is teacher-centred (Halim, 2013; Saat \& Ismail, 2006), where many teachers invest heavily in preparing their students for examinations, at the expense of the practical elements of the 
curriculum (Ministry of Education Malaysia, 2013). Teachers who adopt this approach sometimes take students' learning for granted. They skipped over science experiments with students since the science practical examinations (in upper secondary level) have been replaced by school based assessment 15 years ago. Consequently, students are lacking sufficient opportunities to be critical, creative and innovative (Hazri et al., 2010).

In recent years, science educators have made an attempt to unravel this problem by adapting STEM education approach. This approach is not merely an integration of science, technology, engineering and mathematics disciplines. It purposefully integrate these disciplines to address real-world problems that are interdisciplinary and complex (Roehrig et al., 2012; Labov et al., 2010) by complementing each other's perspectives and explanations on specific situations (Breiner et al., 2012) through the adoption of 21st century skills, namely adaptability, complex communication, social skills and systems thinking (Rodger, 2010).

Likewise, through systemic planning and execution of the Malaysia Education Blueprint 2013-2015 (MEB), Malaysian Ministry of Education defines its concept of STEM Education as a life-long learning approach. The STEM initiatives are to nurture STEM-literate students who are capable of logical thinking, adept at using technology, have the skills to solve problems, innovate, create new ideas, design or invent new products; skills which shall be acquired through an integrated learning of STEM, and a teaching and learning process which apply the real world context through open-ended exploration and hands-on approach.

Grounded on this perspective, one can reckon that STEM will bring about innovations (apart from long-term economic growth) (Bianchi \& Giorcelli, 2017) that will significantly impact people's life. STEM - driven innovations should be able to rectify world problems including people's daily problems and environmental setbacks. Nevertheless, are innovations that resulted from STEM alone can solve the problems? What could be the resistance to the utilization of the STEM-driven innovations? This paper aims to answer these questions by investigating the way people perceive a STEM-driven innovation. Particularly, the STEM-driven innovation that this study focuses on is the reverse vending machine (RVM).

\section{Reverse Vending Machine Values to Promote Environmental Conservation among Public}

Reverse vending machine (RVM) is an innovation that intended to promote recycling practices. RVM may inspire people to recycle as it offers cash rewards or other benefits such as coupons. Users will receive their rewards when they insert recyclable items into the machine. The function of each RVM could be diverse between manufacturers. Some machines do not merely collect items but will also compact and sort the items inserted into the machine (Morishita \& Chung, 2014). Other functions of the RVM include storing and issuing transaction information, and displaying messages and other information to users on a monitor.

This innovative concept helps collect recycling materials effectively and hence boost up recycling activities and consequently improve the waste management. Numerous countries have provided reverse vending machine to their community. The machine especially popular in the countries where recycling laws or legislation is required (Gaur et al., 2018). In these countries, RVM is seen as a tool to help and facilitate the community in compliance with established laws 
and legislation. RVM is also used to encourage community to properly dispose recyclable materials (Tomari et al., 2017) by using egocentric value approach.

Egocentric value approach is one of the tripartite classification of reasons for performing pro-environmental actions, besides biospheric and altruistic. Egoistic value approach is concerned with the well-being of the self or the inner circles; biospheric value orientation is concerned with perceived costs and benefits for the ecosystem; and altruistic value orientation is concerned with perceived costs and benefits for other people or a human group (Lee, 2011; de Groot \& Steg, 2008).

The egocentric value approach in RVM could be the strategy to produce instant outcomes in encouraging the participants to practise recycling by enticing them with the personal benefits. As Casey and Scott (2006) suggest, younger people have a tendency to lean more towards such approach. However, this approach is open to dispute. Egoistic value approach in the literature on deep ecology (e.g. Naess, 2015; Kober, 2013) however, has been considered to be a shallow approach for bringing about lasting environmental behaviour change. There is a peril that it would give people wrong ideas about how they could manipulate the environment for their own benefit.

The studies by Hansla et al. (2008) and Joireman et al. (2001) deliberate this idea. According to Hansla et al. (2001), "environmental concern for self, others, and the biosphere were related to awareness-of-consequences beliefs for oneself, others, and the biosphere, respectively". If someone perceives learning based primarily on concern for themselves, there is a possibility that subsequent future consequences are also for their own benefit (Joireman et al., 2001).

Based on this dispute, it is expected that the value orientation in the utility of RVM is worth attention while investigating how people perceive a STEM-driven innovation. By understanding their values orientation, we can plan forward the subsequent actions to take in as values characterise cultural groups, societies and individuals, and how these people may change their behaviour over time (Schwartz, 2012; Francis, Ong'ayo \& Adams, 2018).

\section{Methodology}

\section{Research design}

The current study adopted qualitative research approach. Qualitative methods were espoused through the lens of constructivist approaches with a slight integration of quantitative methods, particularly at the stage of data analysis. Qualitative methods are the most appropriate approach due to its ability to describe a phenomenon that is locally constituted (Silverman, 2011), which is in the Malaysian context. Constructivists argue that reality and knowledge are subjective and socially constructed (Arthur et al., 2012; Feilzer, 2010).

\section{Sampling and Research Participants}

In order to investigate the resistance to utility of the STEM-driven innovations, we reviewed how Malaysians perceive the use of RVM in the country. This defines the whole possible 
population from which the sample would be drawn. Sampling procedures in qualitative research are flexible. They are not so rigidly prescribed in comparison to quantitative research (Coyne, 1997). In response to that, the current research participants were identified using convenience (accidental) sampling.

Convenience sampling maybe be disputed in term of its rigour. Farrokhi and MahmoudiHamidabad (2012) suggest that the participants who are recruited using convenience sampling may constitute an extreme group of people (extreme in terms of any aspect) which does not allow them to be considered comparable to, or representative of, the wider possible population. However, we decided to proceed with this method due to its strengths. Convenience sampling involves the selection of the most accessible participant (Marshall, 1996) as they happened to be situated, spatially or administratively, within the range where we conducted data collection (Etikan et al., 2016; Kasasbeh, 2018).

\section{Data Collection}

Qualitative data were collected based on how Malaysian Facebook users responded to an article posted on a Facebook group page about RVM in Germany. The group page was followed by 208,765 people. The post was made on August, 252018 . Within four weeks, the posted article received 281 comments, 8334 share and 7052 like by Facebook users. In this study, the comments were used as the qualitative research data. This method of data collection was adopted due to the influence by literatures on the power of social media as a research tool. There has been a proliferation of literatures that signifies social media as a powerful tool for information seeking (Whiting \& Williams, 2013). The key features of social media also enabled collection of huge quantities of data globally (McCay-Peet \& Quan-Haase, 2017; Whiting \& Williams, 2013) - i.e. Malaysian participants that live in Malaysia and outside Malaysia.

\section{Data Analysis}

Research data was analyzed using nested analysis approach. The analysis is considered as nested in a way that it combines descriptive quantitative analysis with a thematic qualitative analysis through deductive and inductive coding and categorizing. Deductive coding and categorizing were made based on the tripartite classification of value orientation - i.e. egoistic, biospheric and altruistic.

\section{Findings}

The article posted received 281 responses in the form of comments from Facebook users. Of these comments, three themes emerged from the thematic analysis performed: egoistic oriented response, biospheric oriented response, and anticipation of the adverse effects of reverse vending machine. Note that there were very few response was altruistic oriented. Therefore, this theme will not be discussed in this paper.

\section{Egoistic Oriented Response}

It is notable from the analysis that the article posted on the Facebook group have sparked 
discussions among Facebook users about the monetary benefits they earned as a result of recycling. Recycling practice in Malaysia today requires people to collect and deliver recyclable items to recycling centers. Recycling centers' operators will then pay the people based on the type and quantity of recyclable items delivered to them. The operation of the recycling centers is privatized and there is no guideline that standardize the value of recyclable items delivered.

Therefore, the discussion on the monetary benefit arising from this article was related to the comparison between the selling prices of recyclable items among recycling centers.

I once sent recyclable items [to a recycling center] that filled the whole car boot. That includes iron products. But, I was only paid RM1.

Refrigerator + washing machine + newspaper $=$ RM 3. This is what I get for sending the items to recycling centre.

It's not worth it to recycle newspaper. But it is for plastic items because they'll pay us more.

These responses suggest that the Facebook users' recycling practices is egoistic oriented, which is concerned with the well-being of the self or the inner circles (Kober, 2013; Schultz, 2001). This finding reflects a statement that such an approach to developing environmental behavior is powerful in turning people's attention to practicing behaviors that sought solutions for environmental problems (Naess, 2015). Numerous empirical studies also have provided evidence to support this claim (Kober, 2013; Fritsche \& Hafner, 2012; Howell, 2012).

\section{Biospheric Response}

Although many participants indicate egoistic attitude, there are also participants that clearly supported the reverse vending machine innovation to promote recycling practices among Malaysians. Some of the supports are biospheric oriented -i.e. concern about the perceived costs and benefits for the ecosystem - and some are altruistic oriented - i.e. concern about the perceived costs and benefits for others. Among of the biospheric oriented responses given are as below.

It's good to have such kind of a machine. Everyone will be more concern about recycling.

Hopefully this machine soon will be available in Malaysia so that junk bottles will no longer clutter around everywhere.

In addition, there were discussions among Facebook users on how RVM could be operated in Malaysia.

Please invent a machine for recycling cigarette buds too. 
The machine should be placed at public spaces where there are many people like shopping malls.

We need this machine in every city.

These comments suggest more favorable attitudes of the Facebook users in comparison to those who perceive RVM for its egoistic benefits, that concerned with perceived costs and benefits for humanity with little regard to their ecological context. In fact, biospheric value orientation in environmental behavior are favoured by ecologists and environmentalists, especially those who preserves deep ecology ideology.

\section{Anticipation of the Adverse Effects of Reverse Vending Machine}

In addition to the above findings, analysis also reveals that some of the participants who left biospheric or altruistic responses are concern about the adverse effects of RVM. In particular, they show their concern about the possibility that the reverse vending machine would be vandalized.

I'm afraid thieves will target this machine.

In Malaysia, this machine will be damaged because people will put in various items at will, without following the proper order.

I doubt the machine will last long.

Perhaps their concern was stimulated by the responses that indicate users' interest on monetary benefit. While this anticipation may not be true, a study by Leh et al. (2017) reveals that vandalism activities have increased due to agro-tourism activities. Therefore from this finding, we suggest that the possibility in which vandalism could be one of the major challenges in improving the quality of the environment should not be overlooked.

Following the comments that were based on the themes mentioned above, few Facebook users suggest that the reverse vending machine will not make any difference to the quality of the environment in Malaysia.

Attitude is what matter. It depends on the person themselves. If you want to do it, even without any refund, you would have done it.

Problematic attitude. We need to change their attitude and mindset. Or else, there is no use to have this machine here.

There have been many campaigns to encourage recycling. This is not the first time. But 
INTERNATIONAL JOURNAL OF ACADEMIC RESEARCH IN BUSINESS AND SOCIAL SCIENCES

Vol. 9, No. 11, November, 2019, E-ISSN: 2222-6990 @ 2019 HRMARS

the results remain the same because the main problem is the mentality of our people.

Based on these extracts, there is an urgency in the need to shift the focus of education by focusing on educating people in a way that will change people's attitude to justify their feelings towards the environment - whether their actions are motivated by biospheric, altruistic or egoistic values orientation.

\section{Discussion and Conclusion}

This study began with the concern about the possible resistance to utility of the STEMdriven innovations. While focusing on RVM as an example of STEM-driven innovation and taking the approach of a qualitative methods, the study reveals that value orientation is the answer. While the invention of RVM could be the solution to solve environmental problem, some people view the innovation for their personal benefit.

These findings are in line with a study that argue that those living in technocratic-industrial societies are unavoidably egoistic This is because the lifestyle of the technocratic-industrial societies nowadays are fundamentally separated from the natural environment (Huckle, 2014; Devall \& Sessions, 2010).

In this paper, we argue that egoistic attitude is the outcome of learning based on indoctrination where behavior change becomes the goal. It remains concerned that the key processes of learning and the motivations for doing so could become subverted (Dobson, 2007; Courtenay-Hall \& Rogers, 2002). Such an idea treats education as being essentially transmissive. By 'transmissive' they mean that behaviors are produced based on a set of facts, skills, and values that are engineered by governments, special-interest groups, or industry, which have preferred messages, agendas, ideologies, or consumer preferences (Jickling \& Wals, 2008).

These critiques show the limitations of the RVM that could be considered as a product of STEM education. The way the machine is operated reflects that we concur that egoistic approaches will produce egoistic attitude. This is an issue because this attitude does not require fundamental changes to the values and practices of individuals nor the transformation of society.

In other words, the transmissive education may not be an ideal transformative approaches to education, if the education does not put emphasis on values. A transformative approach in education as described in the literature of environmental education is the result of social reproduction, social efficiency and confrontation towards global injustice, which involve proper judgment to decide which values are right or wrong in certain circumstances (Jickling \& Wals, 2008; Ashley, 2005).

The transformative approach of education is apparent in the current general education system in Malaysia. In 2011, a new curriculum called the Standard Curriculum of Primary/Secondary School was introduced to emphasis higher order thinking skills to encourage students to develop reasoning skills to help make judgments in applying their knowledge (Ministry of Education Malaysia, 2013). So, what hold the public to change their perceived values of the environment?

STEM education should develop thinking citizens. 'Thinking citizens' refers to those who 
are able to think and make their own decisions based on sound judgment in determining what counts as proper behavior (Ashley, 2005; Courtenay-Hall \& Rogers, 2002). The egoistic attitude support a claim about the adverse effect of modern science and technologies to educational, scientific and social fields in Islamic countries. The argument was drawn from the idea that modern science has been rather silent about Allah SWT and responsibilities towards society and the world, apart from responsibilities to self (Abdullah, 2015).

As an Islamic country, instead of aiming to develop innovation and specific forms of behavior, we wish to urge STEM teachers and STEM curriculum developers in Malaysia to focus on the development and mastery of scientific and technology literacy as well as attitude development in order to help students possess appropriate emotions and values. The Quran and the Hadith could serve the parameter to guide which emotions and values are right.

\section{Corresponding Author}

Sharifah Intan Sharina Syed Abdullah (PhD), Faculty of Educational Studies, Universiti Putra Malaysia (UPM), 43400 Selangor, Malaysia

Email: sharifahintansharina@upm.edu.my

\section{References}

Abdullah, A. (2015). Can religion have a place in modern science? International Conference on Aqidah, Dakwah and Syariah, 1-15.

Arthur, J., Waring, M., Coe, R., \& Hedges, L. V. (2012). Research Methods \& Methodologies in Education. London: Sage Publications.

Ashley, M. (2005).Tensions between indoctrination and the development of judgement: the case against early closure. Environmental Education Research, 11(2), 187-197.

Bianchi, N., \& Giorcelli M. (2017). STEM Degrees Are Good for Careers. But Do They Lead to More Innovation? Retrieved from https://insight.kellogg.northwestern.edu/article/do-stemdegrees-increase-innovation

Breiner, J. M., Johnson, C. C., Harkness, S. S. \& Koelher, C. M. (2012). What is STEM? A discussion about conceptions of STEM in education and partnerships. School Science and Mathematics, 112(1), 3-11.

Casey, P. J., \& Scott, K. (2006). Environmental concern and behaviour in an Australian sample within an ecocentric-anthropocentric framework. Australian Journal of Psychology, 58(2), 57-67.

Courtenay-Hall, P., \& Rogers, L. (2002). Gaps in mind: Problems in environmental knowledgebehaviour modelling research. Environmental Education Research, 8(3), 283-297.

Coyne, I. T. (1997). Sampling in qualitative research. Purposeful and theoretical sampling; merging or clear boundaries? Journal of advanced nursing, 26(3), 623-630.

Devall, B., \& Sessions, G. (2010). Deep ecology. Technology and Values: Essential Readings, 45459.

Dobson, A. (2007) Environmental citizenship: towards sustainable development. Sustainable Development, 15(5), 276-285. 
Etikan, I., Musa S. A., \& Alkassim, R. S. (2016). Comparison of convenience sampling and purposive sampling. American journal of theoretical and applied statistics, 5(1), 1-4.

Farrokhi, F., \& Mahmoudi-Hamidabad, A. (2012). Rethinking convenience sampling: Defining quality criteria. Theory and Practice in Language Studies, 2(4), 784.

Feilzer, M. Y. (2010). Doing mixed methods research pragmatically: Implications for the rediscovery of pragmatism as a research paradigm. Journal of Mixed Methods Research, $4(1), 6-16$.

Francis, Ong'ayo, O. D., \& Adams, Y. (2018). An Analysis of Relationship between Relevance at the Lexical and the Phrasal levels of Financial Budget Discourse Texts. International Journal of Academic Research in Progressive Education and Development, 7(1), 111-120.

Fritsche, I., \& Hafner, K. (2012). The malicious effects of existential threat on motivation to protect the natural environment and the role of environmental identity as a moderator. Environment and Behavior, 44(4), 570-590.

Gaur, A., Mathuria, D., \& Priyadarshini, R. (2018). A Simple Approach to Design Reverse Vending Machine. International Journal of Electronics, Electrical and Computational System, 7(3), 110-119.

Groot, D. J. I., \& Steg, L. (2008). Value orientations to explain beliefs related to environmental significant behavior how to measure egoistic, altruistic, and biospheric value orientations. Environment and Behavior, 40(3), 330-354.

Halim, L. (2013). Syarahan Perdana: Pendidikan Sains dan Pembangunan Masyarakat Beliterasi Sains, Bangi: Penerbit UKM.

Hansla, A., Gamble, A., Juliusson, A., \& Garling, T. (2008). The relationships between awareness of consequences, environmental concern, and value orientations. Journal of Environmental Psychology, 28(1), 1-9.

Hazri, J., Razak, N. A., Ahmad, M. Z., \& Issa, J. (2010). A Study of the policies and practices of teacher education in Malaysia towards producing quality pre-service teachers. Second East Asian International Conference on Teacher Education Research, Hong Kong.

Howell, R. A. (2012). Promoting lower-carbon lifestyles: the role of personal values, climate change communications and carbon allowances in processes of change. The University of Edinburgh. Doctorate Thesis.

Huckle, J. (2014). Education for Sustainable Citizenship: an emerging focus for education for sustainability. Education for sustainability, 228-243.

Jickling, B., \& Wals, A. E. (2008). Globalization and environmental education: looking beyond sustainable development. Journal of Curriculum Studies, 40(1), 1-21.

Joireman, J. A., Lasane, T. P., Bennett, J., Richards, D., \& Solaimani, S. (2001). Integrating social value orientation and the consideration of future consequences within the extended norm activation model of proenvironmental behaviour. British Journal of Social Psychology, 40(1), 133-155.

Kasasbeh, I. (2018). Problems of Management Accounting Implementation. The Case of Balanced Scorecard Implementation within Jordanian Commercial Banks, International Journal of Academic Research in Accounting, Finance and Management Sciences 8 (2): 200-207. 
INTERNATIONAL JOURNAL OF ACADEMIC RESEARCH IN BUSINESS AND SOCIAL SCIENCES

Vol. 9, No. 11, November, 2019, E-ISSN: 2222-6990 @ 2019 HRMARS

Kober, G. (2013). For they do not agree in nature: Spinoza and Deep Ecology. Ethics \& the Environment, 18(1), 43-65.

Labov, J. B., Reid, A. H. \& Yamamoto, K. R. (2010). Integrated biology and undergraduate science education: a new biology education for the twenty-first century?. CBE-Life Sciences Education, 9(1), 10-16.

Lee, K. (2011). The role of media exposure, social exposure and biospheric value orientation in the environmental attitude-intention-behavior model in adolescents. Journal of Environmental Psychology, 31(4), 301-308.

Leh, O. L. H., M. Noor, M. H. C., Marzukhi, M. A., \& Musthafa, S. N. A. M. (2017). Social impact of agro-tourism on local Urban residents. Case study: Cameron Highlands, Malaysia. Planning Malaysia Journal, 15(2), 51-66.

Marshall, M. N. (1996). Sampling for qualitative research. Family practice, 13(6), 522-526.

McCay-Peet, L., \& Quan-Haase, A. (2017). What is Social Media and What Questions Can Social Media Research Help Us Answer? The SAGE Handbook of Social Media Research Methods, 13-26.

Ministry of Education Malaysia. (2013). Malaysia Education Blueprint 2013-2025. Putrajaya: MOE.

Morishita, K., \& Chung, D. (2014). U.S. Patent No. 8,851,265. Washington, DC: U.S. Patent and Trademark Office.

Naess, A. (2015). Ecology: The shallow and the deep. In Cahn, M.A. \& O’Brien, R. Thinking About the Environment: Readings on Politics, Property and the Physical World.

Rodger, W. Y. (2010). What is STEM Edcuation? Science, 329(5995), 996.

Roehrig, G. H., Moore, J. T., Wang, H. H., \& Park, M. S. (2012). Is adding the Eenough? Investigating the impact of K-12 engineering standards on the implementation of STEM integration. School Science and Mathematics, 112(1), 31-44, 2012.

Saat, R. M., \& Ismail, N. A. (2006). Instructional strategies and science achievement of Form 2 students in Malaysia: Findings from TIMSS 2003. Journal of Science and Mathematics Education in Southeast Asia, 29, 1, 62-78.

Schultz, P. W. (2001). The structure of environmental concern: Concern for self, other people, and the biosphere. Journal of Environmental Psychology, 21(4), 327-339.

Schwartz, S. H. (2012). An overview of the Schwartz theory of basic values. Online readings in Psychology and Culture, 2(1), 11.

Silverman, D. (2011). Interpreting qualitative data. London, Sage.

Tomari, R., Kadir, A. A., Zakaria, W. N. W., Zakaria, M. F., Wahab, M. H. A. \& Jabbar, M. H. (2017). Development of reverse vending machine (RVM) framework for implementation to a standard recycle bin. Procedia Computer Science, 105, 75-80.

Whiting, A., \& Williams, D. (2013). Why people use social media: a uses and gratifications approach. Qualitative Market Research: An International Journal, 16(4), 362-369. 